\title{
Freedom of Religion and Social Conflict
}

\author{
Ph.D Candidate Evalda Jera
}

\author{
Part-time Professor at "Luigj Gurakuqi", Shkoder, Albania
} evaldajera@yahoo.com

\section{Doi:10.5901/ajis.2014.v3n3p553}

\begin{abstract}
Today, more and more human rights and fundamental freedoms constitute the essence of human existence and peace through the world. Fundamental human rights are based in each religious tolerance, but unfortunately we must also considerate some evident developments in the practice of human rights that do not support the same idea, tolerance. The expression of religious belief in some situations degrades towards terrorism as an extreme expression of religious faith. So a social conflict comes as the result of wrong prosecution of religious ideologies. Therefore it is very important that religious freedom to demand the implementation should be done through peaceful means respecting the laws, ethical norms and norms of religious tolerance, not with extreme expressions of religious faith causing chaos in the modern world. Faith can affect the individual, group, society or even the nation itself, playing an essential role within society or peripheral depending on this scale. So fundamental human rights specifically are very important and form the basis for the consolidation of the rule of law.
\end{abstract}

Keywords: religion, humans, freedom, social, conflict,

Conflicts between different civilizations have always been a popular topic over the history of the world. As it is seen often religion can cause social conflicts. The importance of religion is expressed on the unity of a social group that it has, and is noticed when we have clashes with another different group. The 20th century is known as nations birth. As we know religion teaches the basics of faith and the manner of implementation by regulating human relations to his Creator, with himself and his family as well as with the society in general. While the nation is a stable community of people, formed historically on the basis of language, territory, economic life and psychological same formation, which today has a synonymous word ethnicity. Every nation has its religion. We can say that religious communities represent a crucial element in the character of each nation. Religion is an important factor of social integration. Symbols of religion represent the unity of a social group, and religious rituals approve that unity, allowing the person symbolically participate in the wider unity that they represen. Religion feeds its members with values and norms also with morality. So religion is a set of beliefs and rituals that are intertwined with the past, present and future of a nation. Civil religion is the expression of a nation's cohesion'. We can say that religion encourages individuals to have at first the interest of group before it's individual. So we can say that civil religion is similar to nationalism, which is reflected by identifying powerful nation when the national interest rises. While building a state on the basis of a nation means that instead, it is developed a sense of solidarity and identity as people of a nation. Political transformation of these states, in nations happened not automatically but depending on several factors including cultural religion. Religion is an important element of this process, providing national vision, making people of different tribal, regional, ethnic and religious meet in a central and unifying cultural experience. Nowdays contacts between peoples of different cultures are increasing, constituteing a vital enrichment, but can also create difficult situations in which the choice between personal and cultural relativism claim inalienable values dramatically. However, if fighting energy if we can define so, released by the clash between two different civilizations runs and channeled in the right direction the contact between two different cultures can be turned into a golden opportunity to open the way to a constructive reflection. So the people has the opportunity to examine their own cultural in light of another culture, different from their own, if it happens and succeed then conflict will not only be avoided, but there will be one more chance to expand the horizon of intellectual culture further. In fact this would be the ideal, but is it possible today to have an independent religious policy, independent from the social conflict? The problem arises precisely when each party believes that coexistence between them is impossible and so the crash is inevitable. As long as the three great Abrahamic faiths will not be able to unify the religious life, conflicts between civilizations will be inevitable. We know

${ }^{1}$ Margins, 2001, p18 
that in today's world there are too many groups or sects which are built on the basis of various faiths, who are often subject to extreme social conflict. Religion has historically intertwined with conflicts at different levels. The main conflict is that between different religious groups especially when they are related with policy. So today, in modern nations the conflict between religious groups is more delicate because it is being combined with other elements such as class, racial or ethnic which brings an open conflict. Another form of conflict can be displayed inside the religious group. This form of conflict may arise as the result of the contradictions that occur within religious groups split off from the trunk becoming a source of conflict. Today there is also an apparent conflict within religious groups, which is associated with the right attitude to moral norms on issues such as abortion or sexuality, also related issues whether sacred text should be taken as literally true or should be construed ${ }^{2}$. Today we also overs face with certain societies which have as their goal to remove religion from social life, by interfering in its essence, which means making ambiguous religion abstract population, and on the other hand aims at the destruction of religion and conscience. Implementation of this practice, so-called secularism incompatible today with the content of democracy and freedom. Religious divisions, can create not only social concerns but also cause weakness in social composition. So in a country where the population has not yet created the exact identity about religion being is uncertainty between the spiritual and moral life. A fundamental problem that occurs more often is the tendency to compare the ideals of a faith practic with another religion, for the main reason to ignoring the other. Something like this undermines the understanding of religion. We can say that religion is a fundamental right which man must feel himself in his conscience and when it is affected by not recognizing it as a unifying factor, this fact not only disrespect the fundamental principles of human rights and freedoms, but also brings the destruction of the peace and social structure. Dialogue between civilizations has become today the puzzle in the global discourse ${ }^{3}$. Today the disappearance of traditional stereotypes has emerged a new scheme of confrontation, giving religious dimensions serious acts of violence and turning into a real conflict. More and more today all areas of human being being oppression by society going troubled by pushing it towards division implying the destruction of the national composition of the society. This is actually a wrong path, that noone should not do it in the name of any particular ideology that inspire religious disruption. Even today in the XXI century continue their existence certain powers which are religious and agains humanity. These structures once again strengthened and weakened by creating chaos in modern society which has the priority to respect the human rights and fundamental freedoms. We can mention horrific terrorist attacks against the World Trade Center. Specifically attacks in New York on 11 September 2001 in fact were attributed to the Islamic religion, but that is not true. True believers of whatever religion will either wish for peace, goodness and prosperity, so that should not fall prey to provocations of anti-religious terrorist gangs. Respect for diversity is related to an universal right. An excellent example of cooperation by religion has been the Cordoba mosque Fridays which was used for prayer by Muslims on Fridays, Saturdays uses Jewish communities and Sundays performed their religious rites Christians. So here it is a truly open society created by the sense of community despite the belief that people could ${ }^{4}$. We can say that secularism or separation of the religion from the state is undoubtedly one of the greatest victories in human history and one of the most important achievements that civilization has produced. So that gives the individes the opportunity to change the conviction to live together in peace enjoying the same rights and the same obligations and this should be protected. It must be said that religion and democracy have in common the concept of recognizing and respecting the other. Today Europe, or the project of European integration and the creation of European space has many dimensions. It is Europe of diversity but also the dialogue of tolerance is exactly in intercultural and in inter-religious dimension. which plays an important role ${ }^{5}$. So religion is a salient factor that separates people from each other. We can say that today's conflicts are not religious wars or conflicts. but unfortunately they use religious justifications. However it should be noted that religion itself is not cause for conflict, but can be used as a factor and as a symbol in the conflict. We are realistic that today religious differences often lead to conflict. The world has so much bigotry and intolerance that a small spark could lead to war when the social, economic, military are not on track. To avoid that policy development and human rights must go together. The role of religion for the maintenance peace and strengthen policy dialogue can not be confined to the level of international geopolitics. Another important aspect of the problem related to the influence of religion in the relationship between groups which belong to a different religious multifunctiona societies. Even in this respect, today's world is like a contradictory historical reality. For by its nature, religion tends towards establishing understanding between individuals in society towards people on establishing the tolerance between different religious beliefs, to on establishing the tolerance among people of different religious beliefs, to strengthen relations and understanding solidarity between

\footnotetext{
2 Stone, 2007, p 326

3 Jahanbeglo, clash of intolerance, Albanian Media Institute, pg 14

4 Jelloun, clash of ignorance, AMI, pg 25

${ }^{5}$ Kokona, 2003, p 102
} 
different social groups. In some regions of the world, seems a phenomenon that is worrying, which appears as a reduction of the social role of religion and spiritual dimensions and expansion of fundamentalist competition. Did not last very long when finished an old division of the world, ideologically bipolar, between capitalist and communist society, who brought so much humanity and apocalyptic disaster on the horizon, now is emerging a new division, instead of showing the ideological character of religious nature. Place need half a century of division, conflict between the West and East Islaike, who should replace Fifty conflict between the West and the communist East, to ensure the integrity ideological militant, the voice seems to be a new division that appears. Religions at their core preach peace but as we know they are often exploited to cause wars. Religious extremism and radicalism is the result of the conflict. Those who caused the Balkan wars in 90 years also encouraged religious extremism which was associated with wars. Peace faded religious clashes. Minret crosses will be more ethnic symbols but will return to religious symbols. In this respect we can say that the wars of religion are enemies since they use the slice. Most of the nations in the region have competed and claimed a territory and claiming a mixed and këtuqëndron main cause of conflicts with permanent stage. Thus movements and conflicts in the region are inspired and caused by ethno-nationalism that deviates from the concept of ethno-territorial. But we must say that the particular role of different cultures and religions to strengthen dialogue and cooperation between individuals and nations in our region gets an even greater importance in today's context. Today, terrorism is presented in the global world in many cases conected to extremisem. This comes as the result of wrong interpretation of religion, justifying terrorism by faith in religion. Interfaith dialogue and intercultural society requires commitment, civil, religious leaders, intellectuals and the respective governments in a highly labor,to stop destructive and destabilizing influence of the extremities In the modern world many common goals and high ideals can not be achieved through assimilation but through integration, not through violence but through dialogue. For this reason dialogue remains the only way forward humanity, which wants to build a better future. Cooperation between religious communities is an important element that can serve as a tool to prevent possible conflicts in the world, being guided by tolerance and respect for the others religious beliefs, also government should always protect the right to freedom of religion as a fundamental right. In principal we all ought to respect and to tolerate diversity respectin also the Article 18 of universal declaration of human rights and the Article 9 and 14 of European Convention of Human Rights.

\section{References}

MC Stone B. M, Religion social context, Center for Public Administration, Logos, 2007

Yalcintas N, Islam the life in global world, Tirana, 2007

Krasniqi M., Tolerance Albanian tradition, science publication Pristina, 2007

Religions and civilization in the new millennium, thecase of Albania, November 14-15 2003. Albanian Center for human rights, Tirana, 2004

Kokona E, Religion and civilization in the new millennium, Tirana 2003

Magris C, Tolerance fair, Albanian institute of media, 2001 